\title{
Jonathan Swift 's Journey of Religious Satire
}

\author{
Xiang Xu \\ College of Foreign Language \\ Qingdao University of Science and Technology \\ Qingdao 266061, China \\ E-mail: stephenxu10@163.com
}

\begin{abstract}
Through close reading of Jonathan Swift's religious works and his novel, this paper traces his deepening critical attitudes towards religion. According to his writing time sequence, the targets of his ridicule become larger and larger, from Roman Catholic and Puritans, to the declining Christianity, and to all religions in general, which reflects his uncompromising stance as an Enlightener.
\end{abstract}

Keywords: Swift, Religion, Christianity, Satire, Enlightenment movement

\section{Introduction}

Jonathan Swift (1667-1745), the greatest satirist of the Enlightenment Movement and of all times, worked as a churchman over thirty years. In 1694, he was ordained Anglican priest, obtaining a small parish in Northern Ireland for about a year. In 1700 Swift became Chaplain to Lord Berkeley and was instituted as Vicar to Laracor, Agher, and Rathbeggan just outside Dublin. In 1713, Swift was appointed Dean of St Patrick's in Dublin, and stayed in that position until 1742, when he resigned due to poor health. As a cleric, he was devoted to his duty, preparing his sermons arduously, serving his congregation full-heartedly, and defending the Church of Ireland militantly. However, his attitude toward church and religion was contradictory. Christianity to him, besides being a profession, was more like a choice in dilemma. An unwavering Enlightener, he never gave up his right of criticizing religion, especially the evil practices of churchmen and dissension among different branches. His criticism can be seen in his religious essays, as well as in Gulliver's Travels, a mastery satire of all the time.

\section{Conflicts between different Christian sects: $\boldsymbol{A}$ Tale of $\boldsymbol{a}$ Tub}

$A$ Tale of a Tub (1704), one of Swift's earliest satire works, is a religious allegory. The book exposes the quarrels of the churches in the famous story of three brothers, Peter (Roman Catholics), Martin (Anglicans) and Jack (Puritans). Their father (God), at his death, bequeaths a coat to each of them, and leaves the will explaining the proper mode of wearing it. They first interpret the will each in their own ways, and then, after many ingenious evasions of it, lock up in a strong box; and then start quarrels concerning the will and its significance. Peter, the eldest son, adds some gilt edges and gaudy decorations; Jack shortens the sleeves and skirt. Only Martin keeps the coat roughly as it used to be. Soon after their father's death, troubles and disputes are emerging among the sons. First, Peter declares that he, the eldest of the family, is the sole heir of his father's will. He demands his brothers address him, not "Brother", but "Mr. Peter", then "Father Peter", or "My Lord Peter", and finally signs the pardon with "Emperor Peter". Besides, he gathers a flock to make some "projects" and "inventions" to cheat people and bully his brothers. At last the two younger ones can no longer bear the suppression, rises against Peter, and are consequently turned out of the house. Later on Jack and Martin also quarrel with each other.

The target of satire in A Tale of $a$ Tub is mainly the Roman Catholics represented by Martin, but the Puritans in image of Jack can't escape Swift's sword either. Only to Anglicans is he tolerably mild. For instance, in Section 4, Swift acidly derides the Roman Catholics' greed, corruption, rigidity and obscurant. To the infamous pardon the author's castigation is merciless. He exposes the Roman Catholics' conceit attempt of prevailing over morality and law and its pretensions to being the will of God.

Whenever it happened that any rogue of Newgate was condemned to be hanged, Peter would offer him a pardon for a certain sum of money, which when the poor caitiff had made all shifts to scrape up and send, his lordship would return a piece of paper in this form: 
'To all mayors, sheriffs, jailors, constables, bailiffs, hangmen, \&c. Whereas we are informed that A. B. remains in the hands of you, or any of you, under the sentence of death. We will and command you, upon sight hereof, to let the said prisoner depart to his own habitation, whether he stands condemned for murder, sodomy, rape, sacrilege, incest, treason, blasphemy, \&c., for which this shall be your sufficient warrant. And it you fail hereof, G--d--mn you and yours to all eternity. And so we bid you heartily farewell.

Your most humble

man's man,

\section{EMPEROR PETER.}

The wretches trusting to this lost their lives and money too. (p 132)

Besides the unscrupulousness of the Roman Catholics, Swift also aims his sword at the other sects of Christianity: he calls Jack's uncontrollable hatred a religious fanaticism, and shows great impatience to Martin's patience in everything.

Because of his violent attack on the church, many people started to doubt the sincerity of Swift's belief. Swift defended himself that what he aimed at was not Christianity, but the abuse of Christianity. However, his defense is not unassailable. A careful reader will find that, not infrequently, this small book full of jests and smears, while ridiculing the practices of the church, undermines some of the divine Christian doctrines, and upsets many real Christians.

\section{A Tongue-in-cheek defense: "An Argument against Abolishing Christianity"}

In 1708, Swift published "Arguments against Abolishing Christianity", a religious essay, in which the narrator argues for the preservation of the Christian religion as a social necessity. Trying to pacify the rising voices advocating the abolition of Christianity, the narrator, with a pose of a patriot worrying about the fate of his nation, refutes the arguments of the abolishers by listing the functions and social benefit of Christianity. Nevertheless, the author does not sing a eulogy against his conscience, but frankly admits all the troubles and defects of Christianity. He firstly makes it clear that what he endeavors to defend is the nominal Christianity instead of the real Christianity, which had long been abandoned in the mist of history.

To offer at the restoring of that, would indeed be a wild project: it would be to dig up foundations; to destroy at one blow all the wit, and half the learning of the kingdom; to break the entire frame and constitution of things; to ruin trade, extinguish arts and sciences, with the professors of them; in short, to turn our courts, exchanges, and shops into deserts; and would be full as absurd as the proposal of Horace, where he advises the Romans, all in a body, to leave their city, and seek a new seat in some remote part of the world, by way of a cure for the corruption of their manners. (p543)

Although the narrator has to accept the fact that the sun of Christianity has already been setting in Christian countries like Britain, and authentic Christian spirit plays little role in people's life, yet to start something totally anew is by no means realistic. The only choice is just to mend and patch to tide over another season.

The author then refutes one by one the arguments of the abolishers. His manner is perfectly serious, but the evidence he provides are just hilarious. For example, to the argument that Christianity restricts free thinking, the narrator answers, that is just why a nominal religion is necessary: "Great wits love to be free with the highest objects; and if they cannot be allowed a god to revile or renounce, they will speak evil of dignities, abuse the government, and reflect upon the ministry, which I am sure few will deny to be of much more pernicious consequence...". Christianity shares at its own expense troubles with the government. What a great sacrifice! To the second argument that the belief of the Gospel system is too difficult for Freethinkers, the narrator replies in surprise: Is not everybody freely allowed to believe whatever he pleases, and to publish his belief to the world whenever he thinks fit, especially if it serves to strengthen the party which is in the right? As to the idea that abolition of Christianity will end disputes among parties and religious branches, the narrator's reply is: "if the physicians would forbid us to pronounce the words pox, gout, rheumatism, and stone, would that expedient serve like so many talismen to destroy the diseases themselves?"( $p 43)$

As to the opinion that abolishing Christianity will save one day each week to promote economy and public entertainment, the narrator's answer is:

... I readily own there hath been an old custom, time out of mind, for people to assemble in the churches every Sunday, and that shops are still frequently shut, in order, as it is conceived, to preserve the memory of that ancient practice; but how this can prove a hindrance to business or pleasure is hard to imagine. What if the men of pleasure are forced, one day in the week, to game at home instead of the chocolate-house? Are not the taverns and coffee-houses open? Can there be a more convenient season for taking a dose of physic? Is not that the chief day for traders to sum up the accounts of the week, and for lawyers to prepare their briefs? But I would fain know how it can be pretended that the churches are misapplied? Where are more appointments and rendezvouses of gallantry? Where more care to appear in the foremost box, with greater advantage of dress? Where more meetings for business? Where more bargains driven of all sorts? And where so many conveniences or incitements to sleep?(p87) 
The church has been reduced from its lofty spiritual position to a mundane gathering place. Swift is forced to defense the existence of religion by highlighting its non-religious function.

Then the author lists the necessity of preserving Christianity: though many daggle-tailed parsons will offend the sight of the gentlemen of wit, they do provide the latter with wonderful material for diversion and for sharpening their tongues and improving their talent. In the same way, the abolition of Christianity will deprive the freethinkers, social reformers and brilliant orators of their best, even the only topic.

Besides other political, religious and moral risks the abolition will cause, the narrator finally exposes his ace: the economical interest that appeals most to his English readers:

To conclude, whatever some may think of the great advantages to trade by this favourite scheme, I do very much apprehend that in six months' time after the Act is passed for the extirpation of the Gospel, the Bank and East India stock may fall at least one per cent. And since that is fifty times more than ever the wisdom of our age thought fit to venture for the preservation of Christianity, there is no reason we should be at so great a loss merely for the sake of destroying it.(P765)

From the above, we can see that the author, by pretending to defend Christianity, demonstrates clearly the deplorable state of Christianity: it is more a habit than a belief, the corruption of the church and folly of parsons are public punching bags and hence, it is just out of convenience for people to keep it. It has nothing to do with spirit and soul.

Notwithstanding, we can detect the author's yearning as an Enlightener. He desired to revive the real Christian spirit and to restore society from its moral degradation, which he knew, would be in vain. With such tongue-in-cheek manner, Swift expresses his longing as a disillusioned social reformer.

\section{Irrationality of religious conflicts and their consequences: Gulliver's Travels}

Swift once said, "We have just enough religion to make us hate, but not enough to make us love one another." This idea is explicitly illustrated in his masterpiece Gulliver's Travels. Through Gulliver's fantastic adventures in such countries as Lilliput, Brobdingnag, Laputa, and the country of the Houyhnhnms, Swift gives a devastating satire to society and human foibles. Through this mirror, the evil and absurdities of the $18^{\text {th }}$ century England are reflected in an exaggerating manner: corruption in politics, evil in religion, impracticality of scientific research, and human weakness such as greed, vanity, and sloth.

In Liliput, a country of people no taller than 6 inches, Gulliver talks about their troubles at home and aggression from abroad. The government is divided into two parties: High Heels and Low Heels, and their variances endanger the nation. Meanwhile, the religious discrepancy has dragged the country into a war as long as 36 months - remember the entire history of the nation is but 6000 months. Upon that, the civil war has also led to a war with a neighboring country Blefuscu.

It began upon the following occasion. It is allowed on all hands, that the primitive way of breaking eggs, before we eat them, was upon the larger end; but his present majesty's grandfather, while he was a boy, going to eat an egg, and breaking it according to the ancient practice, happened to cut one of his fingers. Whereupon the emperor his father published an edict, commanding all his subjects, upon great penalties, to break the smaller end of their eggs. The people so highly resented this law, that our histories tell us, there have been six rebellions raised on that account; wherein one emperor lost his life, and another his crown. These civil commotions were constantly fomented by the monarchs of Blefuscu; and when they were quelled, the exiles always fled for refuge to that empire... During the course of these troubles, the emperors of Blefusca did frequently expostulate by their ambassadors, accusing us of making a schism in religion, by offending against a fundamental doctrine of our great prophet Lustrog, in the fifty-fourth chapter of the Blundecral (which is their Alcoran). This, however, is thought to be a mere strain upon the text; for the words are these: 'that all true believers break their eggs at the convenient end.'(P432)

The wars among these tiny people remind us of the countless massacres and domestic disturbance in British history and the lasting wars between England and France, triggered off by religious disagreement. When we reexamine those bloody wars through the eye of Gulliver looking at the Lilliputians, the bone of contention, which seems so vital, is actually as insignificant as from which end to break an egg. However, just these trivial disputes cause such great disaster. What unreasonable creatures human beings are!

In Brobdingnag, Gulliver, out of dignity or vanity, boasts to the king of the giants about the great achievement of England. After careful listening to the innumerable political conflicts and the description of killing machines that Gulliver is proud of, the king of penetrating mind concludes "the bulk of your natives to be the most pernicious race of little odious vermin that nature ever suffered to crawl upon the surface of the earth."

While staying with the Houyhnhnms, Gulliver tells his wise horse master of the bloodshed caused by religious disagreement: 
Difference in opinions has cost many millions of lives: for instance, whether flesh be bread, or bread be flesh; whether the juice of a certain berry be blood or wine; whether whistling be a vice or a virtue; whether it be better to kiss a post, or throw it into the fire... Neither are any wars so furious and bloody, or of so long a continuance, as those occasioned by difference in opinion, especially if it be in things indifferent. (P90)

When the man-made holy coat is stripped off the religious issues, and religion is restored to its original position, we will realize all the disputes, seemingly as vital as life, are really something naïve and ridiculous.

Gulliver tries to persuade his horse master that he is different from yahoos. We human beings have reason and wisdom, high moral standard and clean habits. But after his account of European history and the history of human civilization, which is characterized by irrational violence and evil, his master interrupts him:

But when a creature pretending to reason could be capable of such enormities, he dreaded lest the corruption of that faculty might be worse than brutality itself. He seemed therefore confident, that, instead of reason we were only possessed of some quality fitted to increase our natural vices...(P57)

After his extensive travels in these countries, Gulliver draws a very pessimistic conclusion on human nature: the greatest evil of humanity is lack of reason, or against reason.

\section{Conclusion}

In $A$ Tale of a Tub Swift attacks mainly Roman Catholics and Puritans, the two branches of Christian church; in "Arguments against Abolishing Christianity", his target is Christianity as a whole; then in Gulliver's Travels, he levels a heavy blow to all religions in general.

The Criticism of Swift experienced an enlarging and deepening process: from accepting one sect of Christianity with conditions, to admitting only its social function, to negation of all religions, the sword of his satire is thrust deeper and deeper. That is closely related to his Enlightenment thinking. After all, which religion can withstand the scrutiny of such a thorough and sharp critical mind?

\section{References}

Swift, Jonathan. (1981). Gulliver's Travels and Other Writings. London: Bantam Books.

Swift. The Cambridge History of English and American Literature in 18 Volumes. [Online] Available: http://www.bartleby.com/219/.

Swift, Jonathan. “An Argument against Abolishing Christianity”, from eBooks@Adelaide. [Online] Available: http://etext.library.adelaide.edu.au/s/s97ab/s97ab.zip.

Fabricant, Carole. (1982). Swift's Landscape. Johns Hopkins University Press.

Jonathan, Swift. [Online] Available: http://www.sparknotes.com/lit/gulliver/. 